\title{
Animal Welfare Attitudes of Pet Owners: An Investigation in Central and Western Parts of Turkey
}

\author{
Gizem S1la SARIAL KUBİLAY' ${ }^{1}$ Zehra BOZKURT $^{2}$
}

1 Avenue Aristide Briand, 38600 Fontaine, France
${ }^{2}$ Afyon Kocatepe University, Faculty of Veterinary Medicine, Department of Animal Husbadry, 03200, Afyonkarabisar, Turkey

\begin{abstract}
Today with the start of global pandemics, the concept of "One health-One welfare" is becoming a fact of life as never before. Responsible ownership and good care duty do affect the health and welfare of pet animals, one of the stakeholders of social life. In this study, pet owners' attitudes towards animal welfare were examined. The research was carried out in Izmir, Ankara and Afyonkarahisar that are located in the Central and Western parts of Turkey. Animal Welfare Attitude Scale (AWAS) was applied to pet owners who voluntarily participated in the study. According to the results obtained in the cognitive dimension of the AWAS, pet owners think that animal welfare is affected mostly by housing, feeding and health conditions, and less by slaughter, sacrifice or naming of animals. Findings regarding the behavioral dimension demonstrated that pet owners treat their pets and street animals well but they do not support non-governmental organizations (NGO) working for animal rights and animal protection and they are not willing to purchase and pay more for foods produced under animal friendly standartds. Also, it has been observed that pet owners believe animals are sensitive beings and have rights like humans, but they agree little with the judgment that animals are created for humans. It was concluded that pet owners can support strategies to increase animal welfare and, increasing pet owners' knowledge and awareness relationships between animals and humans, values and norms as well as NGOs can provide valuable opportunities for increasing animal welfare in Turkey.
\end{abstract}

Key Words: Animal welfare, Attitudes, Owner, Pet animal

\section{Pet Hayvanı Sahiplerinin Hayvan Refahı Tutumu: Türkiye'nin Orta ve Batısında Bir Araştırma}

\section{ÖZ}

Günümüzde küresel pandemilerin başlamasıyla birlikte "Tek sağlık-Tek refah" kavramı hiç olmadığı kadar hayatın bir olgusu haline gelmektedir. Sorumlu sahiplik ve iyi bakım toplumsal yaşamın paydaşlarından birisi olan pet hayvanlarının sağlığı ve refahını etkilemektedir. Bu araştırmada pet hayvan sahiplerinin hayvan refahına yönelik tutumları incelenmiştir. Araştırma Türkiye'nin orta ve batısında yer alan İzmir, Ankara ve Afyonkarahisar'da yürütülmüştür. Araştırmaya gönüllü olarak katılan pet sahiplerine Hayvan Refahı Tutum Ölçeği (AWAS) uygulanmıştır. Hayvan refahı tutumunun bilişsel boyutunda elde edilen sonuçlara göre pet sahipleri hayvan refahının en çok barınma, besleme ve sağlık koşulları, en az hayvanların kesilmesi, kurban edilmesi veya onlara isim verilmesi ile etkilendiğini düşünmektedir. Davranışsal boyuta ilişkin bulgular pet sahiplerinin kendi hayvanlarına ve sokak hayvanlarına iyi davrandıklarını ancak hayvan hakları ve hayvan koruma konusunda faaliyet gösteren sivil toplum örgütleri (STK)'ni desteklemediklerini ve yüksek hayvan refahı standartlarında üretilen hayvansal gıdaları satın alma ve daha fazla ödemeye istekli olmadıklarını ortaya koymuştur. Ayrıca evcil hayvan sahiplerinin hayvanların hassas varlıklar olduğu ve insanlar gibi haklara sahip olduklarına inandıkları ancak hayvanların insanlar için yaratıldığı yargısına daha az katıldıkları görülmüştür. Pet hayvan sahiplerinin, hayvan refahını arttırmaya yönelik stratejileri destekleyebilecekleri ve pet hayvan sahiplerinin hayvanlar ve insanlar arasındaki ilişkiler, değerler ve normlar ile STK'larla ilgili bilgi ve farkındalı̆̆ının artırılmasının Türkiye'de hayvan refahının artırılması için değerli firsatlar sağlayabileceği sonucuna varılmıştır.

Anahtar Kelimler: Hayvan refahı, Tutum, Sahip, Pet hayvanı

To cite this article: Sarial Kubilay G.S., Bozkurt Z. Animal Welfare Attitudes of Pet Owners: An Investigation in Central and Western Parts of Turkey. Kocatepe Vet J. (2020) 13(4)388-395

Submission: 14.09.2020 Accepted: 08.11.2020 Published Online: 20.11.2020

ORCID ID; GSSK: 0000-0002-8203-2123, ZB: 0000-0001-8272-7817

*Corresponding author e-mail: zhra.bozkurt@gmail.com 


\section{INTRODUCTION}

In the last decades, environmental and animal protection awareness has increased due to climate change and public health crises (Scott 2004, McMichael 2013). Animal protection activist's efforts and global lobbying activities that were aimed to informing people about animal welfare and rights have led to changes in legislation around the world and specifically in the EU on companion, farm and laboratory animals (Odendaal 1988, Boissy et al. 2007, Broom 2017, De la Fuente et al. 2017). In 2013, the European Union initiated studies on welfare of cats and dogs in commercial practices within the scope of animal welfare strategy of 2012-2015. Although there is no specific EU regulation on pet animal welfare yet, there are EU regulations that cover identification (Regulation (EC) No 998/2003, Regulation (EU) No 576/2013, Commission Implementing Regulation (EU) No 577/2013, Council Directive 92/65/EEC), movements (Council Regulation (EC) No 1/2005, Commission Decision 2003/803/EC, Council Directive 92/65/EEC), protection in animal breeding (Council Directive 98/58/EC) and health (Commission Decision 2004/824/EC) of pet animals. Turkey signed the European Convention on Protection of Pet Animals in 1999, and accepted European Union approaches in this area. Except for Law No 5199 on Animal Protection and implementing regulation thereof (dated 12.05.2006 and No 26166), there is no specific regulation on pet animal welfare in Turkey. However, within Turkey's accession negotiations for full membership to EU, several studies for aligning national legislation with the EU legislation on welfare of pet animals continued since 2011.

Legislative sanctions aside, the first step to encourage a worldwide change in people's attitudes concerning animal protection is understanding people's perceptions and attitudes in relation to this issue (De la Fuente et al. 2017, Bozkurt and Sarral Kubilay 2019). Although there are many factors that have potential to affect pet animal welfare, it is essential to determine the effects of general and specific factors on the human being that are the basis of owner or caregiver behavior (Kirk 2019). Pet owner's duty of care includes social, ethical and public health concepts (Glanville et al. 2020). Besides being a moral duty of protection of animals whose responsibility is assumed, the pet owners' attitudes and behaviors directly affect the welfare of animals. Because pet owners are the people who are providing care, housing and social needs of pet animals (Odendaal 1994, Sanderson et al. 2005, Michel et al. 2008, Slater et al. 2012). Animal welfare perceptions and attitudes are influenced by personal characteristics such as sociodemographic traits (Paul and Serpell 1993, Reevy and Delgado 2015) and values and beliefs
(Glanville et al. 2020). Taylor and Signal (2005) reported that those who live with a pet animal have more positive animal welfare attitudes.

Pet owners know the behavioral characteristics of their pets best and they can best understand whether their pets are stressed or not. Therefore, participation of the pet owners in the surveys provides valuable findings in the domain of pet animal welfare (Mariti et al. 2012, Stamps and Groothuis 2010). Mariti et al. (2012) reported that awareness of owners on stress level and well-being of pets play a key role. A good understanding of pet owner's perceptions and attitudes on animal welfare can help increase the welfare of their pets by leading to an increase in the quality of pet care and management (Michel et al. 2008). Paul and Serpell (1993) reported that the results to be obtained by analyzing pet owner's attitudes towards animal welfare can contribute to the development of effective humane education interventions and programs.

The need for the protection of pet animals have increased further with the economic growth of the pet sector. The pet sector is attracting the attention of global markets more than ever before because of pet owners' purchasing behavior for their fur-babies, including health, plastic surgery, spa treatments, foods, accessory and designer clothes (Holbrook and Woodside 2008, Guzman 2017, Haldeman 2018, Kirk 2019). The global size of the pet products and services industry is billions of dollars (American Pet Products Association 2018). There are 66 and 61 million cat and dog owners in the European Union (European Dog\&Cat Alliance 2019). It is estimated that there are at least one pet animal in 1.5 million households and a pet sector with a transaction volume of more than 2 billion dollars per year in Turkey (Anonymous 2019). The objective of this study was to examine the attitudes of Turkish pet owners towards animal welfare living in Central and Westesn parts of Turkey.

\section{MATERIALS and METHODS}

\section{Survey implementation and data collection}

The study was conducted in Izmir, Ankara and Afyonkarahisar that were located in Central and Western of Turkey. The pet owners volunteered to participate in the survey after the scientific objectives of the study were explained to them. The sample size for the cities were determined according to the method applied by K1lıç and Bozkurt 2020. Consideringly the minimum sample size for each region a total of 940 pet owners who has at least one cat or dog were participated in the survey. Animal Welfare Attitude Scale (AWAS), developed by Kulıç and Bozkurt (2020) was applied to examine pet owner's attitudes regarding animal welfare. The questionnaires that were determined to be a contradiction in the answers given to similar questions, or to be imperfect or incorrect data were 
excluded, and then the statistical analyzes were done with the 916 questionnaires. In the first part of the AWAS there are the questions about the age, gender and educational background of the animal owners. The questions measuring attitudes towards animal welfare in terms of cognitive (20 items), behavioral (11 items) and affective (10 items) dimensions are in the second part of the scale. Animal welfare attitude scale was applied to pet owners individually and via face to face interviews. The research was summarized from the first author's master's thesis numbered 2019-008 and approved by AKÜHADYEK (Reference no: AKUHADYEK-245-17).

\section{Statistical analysis}

The items in cognitive, behavioural and affective dimensions within AWAS scale were applied to pet owners to evaluate their level of agreement according to the 5-point Likert Type rating (1: Strongly Disagree, 2: Disagree, 3: Neutral, 4: Agree, 5: Strongly Agree). The attitudes regarding animal welfare of pet owners were described by calculating the frequency and percentages, means and standard deviations for each dimension and items. All data were analyzed with SPSS 18.0 for Windows (SPSS, Inc., Chicago).

\section{RESULTS}

The findings regarding the demographic characteristics of pet owners participating in the study are presented in Table 1. The rates of female and male pet owners were 63.31 and $36.69 \%$. The percentage of participants that were aged 18 and younger, 19-25, 26-32, 33-39 and 40-50 years old and 51 and older were 5.42, 51.09, 22.38, 9.61, 7.31 and $4.37 \%$ respectively. The majority of the participants were university graduate $(69.65 \%)$ and high-school graduate $(19.65 \%)$ while $3.38 \%$ and $7.32 \%$ of them were primary and secondary school graduate.

Descriptive statistics regarding the cognitive dimension of the AWAS scale are given in Table 2. The pet owners were in more positive agreement with the arguments "C3. Animal health conditions affect animal welfare" $(\bar{X}=4.59)$, "C2. Animal feeding requirements affect animal welfare" $(\bar{X}=4.58)$ and "C1. Conditions of shelter affect animal welfare" $(\bar{X}=4.52)$ under cognitive dimention of AWAS scale. The participants showed the lowest agreement for the items "C15. Religious sacrificing of the animals affect animal welfare" $(\overline{\mathrm{X}}=3.39)$, "C12. Slaughtering of livestock affect animal welfare" ( $\overline{\mathrm{X}}=3.62)$, and "C13. Naming animals affect animal welfare" ( $\overline{\mathrm{X}}=3.62)$.

The results regarding the behavioral dimension of the AWAS scale are presented in Table 3 . Under affective dimension of the scale, the respondents approved the arguments with the highest rate "B8. I always behave animals well" ( $\overline{\mathrm{X}}=4.52)$, "B5. I treat to street animals with compassion" ( $\overline{\mathrm{X}}=4.39)$, and "B4. I encourage people to treat animals well" ( $\bar{X}=4.38)$ as well as the lowest rates were given to the items "B11. I buy food products produced under high animal welfare standards even if they are expensive" ( $\bar{X}=3.80)$, "B6. I support the civil society organizations involved in animal protection" $(\overline{\mathrm{X}}=3.87)$, “B10. I buy food products that have been produced in compliance with high animal welfare standards" $(\overline{\mathrm{X}}=3.96)$, and "B2. Animal welfare issue affect my choices when purchasing animal food products" $(\overline{\mathrm{X}}=3.96)$.

In Table 4, the descriptive statistics concerning affective dimension of the animal welfare attitude scale were presented. The results obtained in this dimension showed that, the highest mean values were calculated for the items "A6. Behave cruel to animals is atrocious" $(\overline{\mathrm{X}}=4.65)$, “A4. I believe animals are sentient beeings" ( $\bar{X}=4.53)$, “A8. I believe that animals have rights like people $(\overline{\mathrm{X}}=4.52)$ " and "A3. I believe that animals have well-being" $(\overline{\mathrm{X}}=4.50)$. The mean value was dramatically lower than the other items for "A2.Animals have been created for human use" $\overline{\mathrm{X}}=2.87)$.

Table 1. The sociodemographic characteristics of the participants

Tablo 1. Katılımciların sosyodemografik özellikleri

\begin{tabular}{llll}
\hline Variable & Groups & Numbers (f) & Percantage (\%) \\
\hline Gender & Female & 580 & 63.31 \\
Age & Male & 336 & 36.69 \\
& 18 and younger & 48 & 5.24 \\
& $19-25$ & 468 & 51.09 \\
& $26-32$ & 205 & 22.38 \\
\multirow{4}{*}{ Education level } & $33-39$ & 88 & 9.61 \\
& $40-50$ & 67 & 7.31 \\
& 51 and older & 40 & 4.37 \\
& Primary school & 31 & 3.38 \\
& Secondary school & 67 & 7.32 \\
& High-school & 180 & 19.65 \\
& University & 638 & 69.65 \\
\hline
\end{tabular}


Table 2: Descriptive statistics regarding the cognitive dimension of animal welfare attitude scale

Tablo 2: Hayvan refahı tutum ölçeğinin bilişsel boyutuna ilişkin betimsel istatistikler

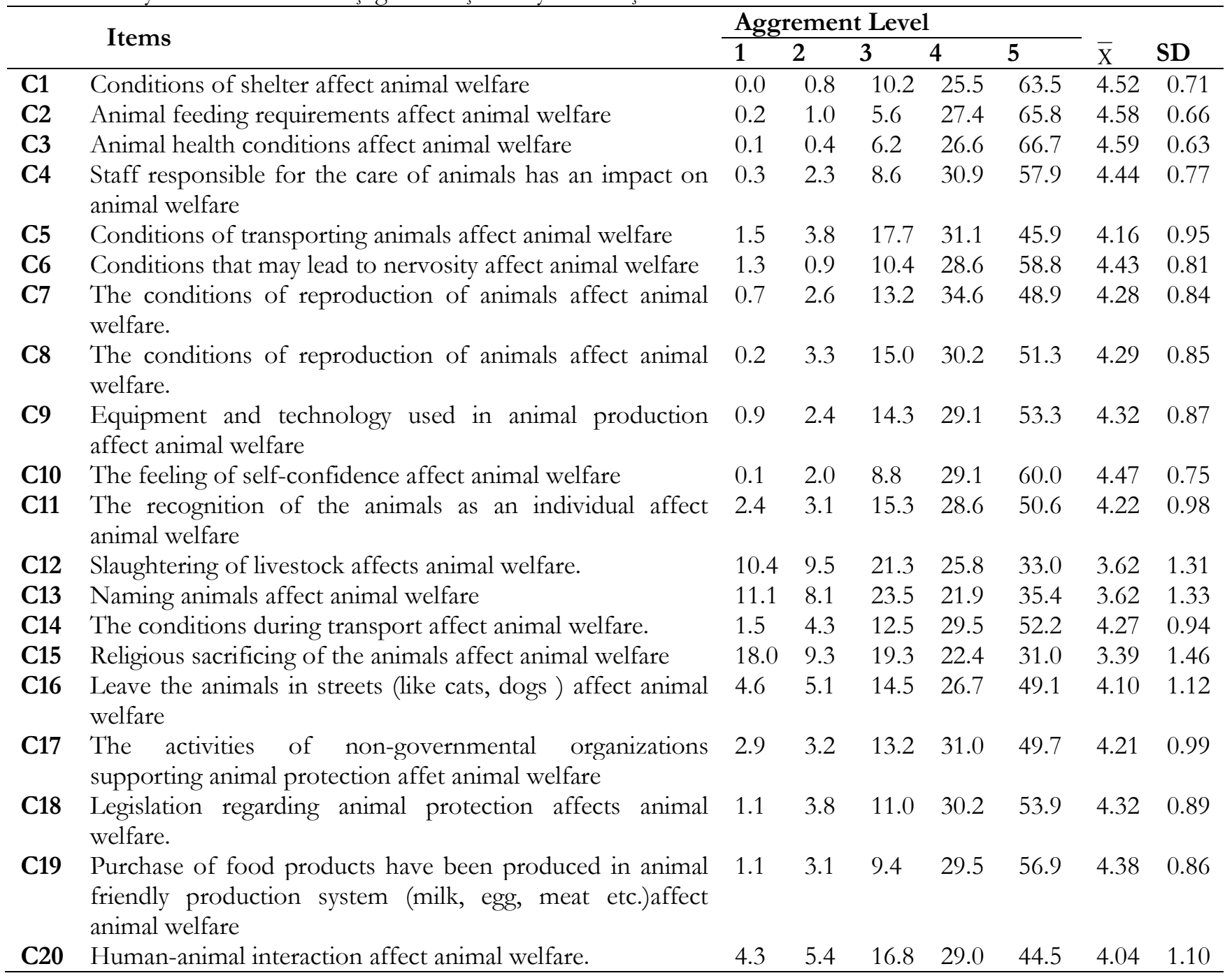

Table 3: Descriptive statistics regarding the behavioural dimension of animal welfare attitude scale

Tablo 3: Hayvan refahı tutum ölçeğinin davranışsal boyutuna ilişkin betimsel istatistikler

\begin{tabular}{|c|c|c|c|c|c|c|c|c|}
\hline & \multirow{2}{*}{ Items } & \multicolumn{5}{|c|}{ Agreement level (\%) } & \multirow[b]{2}{*}{$\overline{\mathrm{X}}$} & \multirow[b]{2}{*}{ SD } \\
\hline & & 1 & 2 & 3 & 4 & 5 & & \\
\hline B1 & I am interested in animal welfare & 2.1 & 4.9 & 16.4 & 26.7 & 49.9 & 4.17 & 1.01 \\
\hline B2 & $\begin{array}{l}\text { Animal welfare issues affect my choices when } \\
\text { purchasing animal food products. }\end{array}$ & 3.5 & 6.6 & 21.9 & 26.1 & 41.9 & 3.96 & 1.10 \\
\hline B3 & I tell people around me about animal welfare & 3.0 & 6.6 & 17.2 & 27.0 & 46.2 & 4.07 & 1.08 \\
\hline B4 & I encourage people to treat animals well. & 0.8 & 2.7 & 10.2 & 30.3 & 56.0 & 4.38 & 0.84 \\
\hline B5 & I treat to street animals with compassion & 1.1 & 1.6 & 12.0 & 27.3 & 58.0 & 4.39 & 0.84 \\
\hline B6 & $\begin{array}{l}\text { I support the civil society organizations } \\
\text { involved in animal protection }\end{array}$ & 6.0 & 8.7 & 18.6 & 25.2 & 41.5 & 3.87 & 1.21 \\
\hline B7 & $\begin{array}{l}\text { I comply with legislation regarding animal } \\
\text { welfare }\end{array}$ & 1.1 & 2.3 & 11.5 & 31.0 & 54.1 & 4.35 & 0.85 \\
\hline B8 & I always behave animals well & 0.0 & 2.0 & 7.7 & 26.9 & 63.4 & 4.52 & 0.72 \\
\hline B9 & $\begin{array}{l}\text { I make required attempts against animal } \\
\text { violence }\end{array}$ & 1.5 & 2.4 & 14.0 & 28.7 & 53.4 & 4.30 & 0.90 \\
\hline B10 & $\begin{array}{l}\text { I buy food products that have been produced in } \\
\text { compliance with high animal welfare standards. }\end{array}$ & 4.5 & 5.5 & 20.5 & 29.0 & 40.5 & 3.96 & 1.11 \\
\hline B11 & $\begin{array}{l}\text { I buy food products produced under the animal } \\
\text { welfare standards even if they are expensive }\end{array}$ & 6.7 & 6.8 & 22.5 & 27.6 & 36.4 & 3.80 & 1.19 \\
\hline
\end{tabular}


Table 4. Descriptive statistics regarding the affective dimension of animal welfare attitude scale

Tablo 4. Hayvan refahı tutum ölçeğinin duyuşsal boyutuna ilişkin betimsel istatistikler

\begin{tabular}{|c|c|c|c|c|c|c|c|c|}
\hline & \multirow{2}{*}{ Items } & \multicolumn{5}{|c|}{ Agreement level (\%) } & \multirow[b]{2}{*}{$\bar{X}$} & \multirow[b]{2}{*}{ SD } \\
\hline & & 1 & 2 & 3 & 4 & 5 & & \\
\hline A1 & I think that animal as an individual & 2.4 & 3.2 & 15.4 & 27.9 & 51.1 & 4.22 & 0.98 \\
\hline A2 & Animals have been created for human use & 32.8 & 11.6 & 14.5 & 18.0 & 23.1 & 2.87 & 1.59 \\
\hline A3 & I believe that animals have well-being. & 0.7 & 3.0 & 7.7 & 23.5 & 65.1 & 4.50 & 0.81 \\
\hline A4 & I belive animals are sentient beings & 0.9 & 2.1 & 6.8 & 24.0 & 66.2 & 4.53 & 0.79 \\
\hline A5 & $\begin{array}{l}\text { I can understand an animal of experience pain and } \\
\text { suffering. }\end{array}$ & 1.1 & 3.1 & 12.1 & 31.0 & 52.7 & 4.31 & 0.88 \\
\hline A6 & Behave cruel to animals is atrocious & 1.1 & 1.4 & 4.9 & 16.4 & 76.2 & 4.65 & 0.74 \\
\hline A7 & $\begin{array}{l}\text { I believe that there is a relationship between } \\
\text { domestic violence and intentional harm against } \\
\text { animals }\end{array}$ & 1.6 & 4.6 & 11.2 & 23.1 & 59.5 & 4.34 & 0.96 \\
\hline A8 & I believe that animals have rights like people & 0.5 & 2.2 & 8.3 & 23.0 & 66.0 & 4.52 & 0.78 \\
\hline A9 & $\begin{array}{l}\text { I believe that attitudes of people regarding animals } \\
\text { affect other peoples' perception of them }\end{array}$ & 0.7 & 2.9 & 9.8 & 25.4 & 61.2 & 4.44 & 0.84 \\
\hline A10 & $\begin{array}{l}\text { I believe that happy animals will produce higher } \\
\text { quality products such as meat, milk, eggs, etc. }\end{array}$ & 1.1 & 2.5 & 13.4 & 27.8 & 55.2 & 4.34 & 0.88 \\
\hline
\end{tabular}

\section{DISCUSSION}

Two-thirds of the pet owners participating in this study were women and Lue et al. (2008) reported similar rates of female participants in a study they conducted with US pet owners. This result was interpreted as women adopting more pets as well as being more involved in animal welfare initiatives and research. The results regarding the affective dimension of famale's animal welfare attitude is more dominant can be supported by this argument (Selby et al. 1981). In parallel with the notifications of PratoPrevide et al. (2006) it was thought that female's have more tendency to interact (such as talking, playing, friendship) with pet animals than males.

Participants were mostly young $(78.71 \%$ younger than 32 years old) and educated $(89.30 \%$ graduated from high school and university). It was thought that socioeconomic and geographical conditions may have lead to this result. It is likely that educated and young participants living in big cities were more motivated to adopt a pet animal to cope with the stress and loneliness caused by living alone and heavy workload (Roudebush et al. 2008, Johnson 2009, Chou 2016). In fact, Erten et al. (2019) reported similar reports on the sociodemographic structure of pet owners living in the Southeastern Anatolia and the Mediterranean regions.

The results regarding the cognitive dimension of the animal welfare attitude scale showed that pet owners believe that the housing, feeding and health conditions of pet animals significantly affect animal welfare. These high animal welfare attitude scores regarding animal health and care are involve favorable opportunities for enhancing pet welfare. Because most of the participants were living in big cities such as Ankara and Izmir and, probably their pets could have been home alone all day and have been significantly restrained. This positive attitudes of pet owners can ensure potential opportunities for cooperation with pet owners to fight againts welfare problems caused by limitation of natural behaviors, insufficient exercise (abnormal behaviors, bone health problems, obesity, etc.) and poor feeding (Kienzle et al. 1998, Rohlf et al. 2010). Also, higher education level of pet owners can provide an important advantage in strengthening responsible ownership. Roudebush et al. (2008) also reported that the education level and motivation of the animal owners are very important to increasing animal welfare.

The results on the cognitive dimension of pet owners suggested, pet owners believe that sacrificing or slaughtering animals and naming animals does not affect animal welfare considerably. This result was found surprising at first glance because there was parallelism in the responses for these items of pet owners with Turkish farmers and farm animal keepers (Kilıç and Bozkurt 2013, Çelik and Bozkurt 2016, Bozkurt et al. 2017). It has been thought that, the participants may have a low level of knowledge and awareness of animal welfare or they may have a perception that naming pet animals are not correlated with animal welfare (Kilıç and Bozkurt 2020). Since, many studies show that people create a strong emotional bond with their pet animals and they behave as if they are family members or their child, and named them usually as if they were individuals (Franklin 1999, Prato-Previde et al. 2006, Johnson 2009). Also, according to the results in the cognitive and behavioral dimensions of the animal welfare attitudes of the participants, it was evaluated that the opinions and behaviors of the participants contained some differences for pet animals and farm animals. Pet owners considered that slaughtering or sacrificing 
livestock has less impact on animal welfare. This approach has been evaluated to be anthropocentric and it may be related to their consumer perception and attitudes. Participants may have not seen cats or dogs as food like farm animals (Wrye 2009). Already, Morris et al. (2012) reported that it is common in humans that cats or dogs have more cognitive abilities and therefore are superior to other animals.

The results on the behavioral dimension of the animal welfare attitude scale demonstrated that the participants always behave well with pet animals and stray animals and they encourage other people to do that. This findings highlights that Turkish pet owners can show strong empathy for stray animals. Moreover, Dodd et al. (2019) and Erten et al. (2019) reported that pet owners have a high tendency to adopt animals from free sources such as animals that have been abandoned or have a high potential for abandonment. These results are very positive because it is understood that pet owners can support strategies and projects to be developed in terms of increasing the welfare of owned or unowned pet animals in the future.

Pet owners have been found to have a low attitude towards purchasing foods produced in animal friendly production systems. This result was similar to attitudes of owners regarding the slaughter of livestock. The reasons such as food purchasing preferences (vegetarianism, veganism, etc.) (Preylo and Arikawa 2008, Foer 2010, Dodd et al. 2019), animal welfare knowledge or socio-economic conditions (Franklin 1999, Jacobson and Chang 2018) may also have been effective on pet owner's attitude. Dodd et al. (2019) reported a higher rate of vegetarians or vegans among pet owners compared to the general population structure.

It has been observed that pet owners are compassionate towards stray animals but their attitudes toward supporting NGOs working in animal protection (especially for protection of stray animals) are negative. In general, our results show that Turkish pet owners have an important sensitivity to protection of the stray animal population. In Turkey since 2005, the main EU legislation has been transposed into national legislation, collaboration has increased between stakeholders and many NGOs have been established in animal protection. However, it is understood that the effects of adapted EU acquis are yet low, activities of NGOs do not reach sufficiently to society for reasons such as communicative, financial and organizational problems and the animal activists' interactions with society via media is also weak ('Talas 2011, Aksulu 2013, Tekvar 2017, Aşar 2018).

In affective dimension of animal welfare attitude scale, pet owners showed the highest participation for the arguments like animals are sentient creatures, animals have rights like humans and it is brutal to mistreat animals. So, pet owners had a dramatically less contributed to the item that animals were created for human use. According to these results, the pet owners admitted the human-animal relationship far from the anthropocentric view and consider animals valuable with a " be sensitivity" approach (Rohlf et al. 2010, Morris et al. 2012, Aşar 2018).

\section{CONCLUSIONS}

The results showed that the affective dimension of the animal welfare attitudes of Turkish pet owners in Central and Western of Turkey is quite strong. However, it seems that the cognitive and behavioral dimensions need to be supported to strengthen the animal welfare attitudes of pet owners. It was concluded that pet owners can support strategies to increase animal welfare and, increasing pet owners' knowledge and awareness relationships between animals and humans, values and norms as well as NGOs can provide valuable opportunities for increasing animal welfare in Turkey.

\section{ACKNOWLEDGMENTS}

This study received the support of Afyon Kocatepe University Scientific Research Projects Coordination Unit with Project number 18.SAĞ.BİL.20 Turkey.

Some data of this study was presented as a oral presentation at Hasat International Agriculture and Forest Congress held in Ankara on 21-23 June 2019.

Ethical statement: The research was approved by AKÜHADYEK (AKÜHADYEK-245-17)

\section{REFERENCES}

Aksulu M. Yeni toplumsal hareketler: Türkiye'de hayvan hakları savunuculuğu ve sosyal medya. Maltepe Üniversitesi Sosyal Bilimler Enstitüsü Radyo Sinema Televizyon Anabilim Dalı. Yüksek Lisans Tezi. 2013; İstanbul.

American Pet Products Association (APPA). National pet owners survey, 2017-2018. American Pet Products Association, Inc. Greenwich,

CT. 2018; (http:/ / americanpetproducts.org/Uploads/MemServic es/GPE2017_NPOS_Seminar.pdf. Erişim:16.08.2019).

Anonymous.

Pet hayvan1 sektörü, 2019(https:/ /www.dunya.com/sirketler/2-milyar-dolarlikpazarda-hektas-hamlesi-haberi-413047, Erişim:21.03.2019).

Aşar H. Hayvan haklarına yönelik temel görüşler ve yanılgıları. Kayg1, Uludağ Üniversitesi Fen-Edebiyat Fakültesi Felsefe Dergisi. 2018; 30:239-251.

Boissy A, Manteuffel G, Jensen MB, Moe RO, Spruijt B, Keeling LJ, Winckler C. Assessment of positive emotions in animals to improve their welfare. Physiology and Behavior. 2007; 92:375-397.

Bozkurt Z, Koçak S, Kılıç İ, Çelikeloğlu K, Hacan Ö, Lenger ÖF, Tekerli M. Attitudes of staff regarding animal welfare: A 
description on poultry farms in Afyonkarahisar. Kocatepe Veteriner Dergisi, 2017; 10(4): 308-316

Bozkurt Z, Sarıal Kubilay GS. Tek sağlık-Tek refah:Başlıca paydaş olarak pet hayvan sahiplerinin rolü. $4^{\text {th }}$ International Anatolian Agriculture, Food, Environment and Biology Congress, 20-22 April 2019, Afyonkarahisar. Congress Proceedings Book, pages;339-342.

Broom DM. Animal welfare in the European Union. Brussels: European Parliament Policy Department, Citizen's Rights and Constitutional Affairs, Study for the PETI Committee. 2017; pp. 2427

Chou Y. The Changing of Social Meanings of Pets and Their Alternative Futures. (Master's Thesis). Tamkang University Graduate Institute of Futures Studies. 2016. (http://www.metafuture.org/pdf/chouthesis.pdf. Erişim:11.05.2019).

Çelik B, Bozkurt Z. The attitudes and perceptions towards animal welfare of staff employed in the care and handling of animals during animal transport in muş province. Kocatepe Vet J 2016; 9(4): 294-303.

De la Fuente MF, Souto A, Caselli C, Schiel N. People's perception on animal welfare: why does it matter? Ethnobiology and conservation. 2017;6.

Dodd SA, Cave NJ, Adolphe JL, Shoveller AK, Verbrugghe A. Plant-based (vegan) diets for pets: A survey of pet owner attitudes and feeding practices. PloS one. 2019; 14(1):e0210806.

Erten Ö, Öztürk Y, Yılmaz, O. Türkiye'de pet hayvan sahiplerinin sosyo-demografik yapıları ve pet hayvancıllğına bakışları; Alanya-Mardin örneği. Mehmet Akif Ersoy Üniversitesi Veteriner Fakültesi Dergisi. 2019; 4(2), 76-83.

European Dog\&Cat Alliance. The welfare of dogs and cats involved in commercial practices:a review of the legislation across EU countries; 2019. (https://www.ispca.ie/uploads/WelfareEU-dogs-cats.pdf, Erişim: 02.01.2019).

Foer JS. Eating animals. 2010; Penguin UK.

Franklin A. Animals and Modern Cultures: A Sociology of HumanAnimal Relations in Modernity.1999; London, UK: Sage Publications.

Glanville CR, Hemsworth PH, Coleman GJ. Conceptualising dog owner motivations: The pet care competency model and role of'duty of care'.Animal Welfare.2020; 29(3), 271-284.

Guzman Z. Owning a pet can cost you $\$ 42,000$, or 7 times as much as you $\quad$ expect. 2017; (https://www.cnbc.com/2017/04/27/how-much-does-itcost-to-own-a-dog-7-times-more-than-you-expect.html.).

Haldeman P. The secret price of pets. The New York Times. 2018; (https://www.nytimes.com/2018/07/04/style/howto-pamper-your-pet.html).

Holbrook MB, Woodside AG. Animal companions, consumption experiences, and the marketing of pets: Transcending boundaries in the animal-human distinction. 2008.

Jacobson KC, Chang L. Associations between pet ownership and attitudes toward pets with youth socioemotional outcomes. Frontiers in Psychology. 2018; 9, 2304.
Johnson J. Dogs, Cats, and Their People: The Place of the Family Pet and Attitudes about Pet Keeping. (A thesis presented to the University of Waterloo in fulfilment of the thesis requirement for the degree of Master of Arts in Public Issues Anthropology. 2009; Waterloo, Ontario, Canada. (https://uwspace.uwaterloo.ca/bitstream/handle/10012/43 79/Johnson_Jill.pdf;sequence=1).

Kılıç İ, Bozkurt Z. Assessment of Turkish consumer attitudes using an Animal Welfare Attitude Scale (AWAS). Veterinaria México OA. 2020; 7(1).

Kılıç I, Bozkurt Z. The relationship between farmers' perceptions and animal welfare standards in sheep farms. Asian Australas. J. Anim. Sci. 2013; 26 ( 9) : 1329-1338.

Kienzle E, Bergler R, Mandernach AA. comparison of the feeding behavior and the human-animal relationship in owners of normal and obese dogs. The Journal of Nutrition. 1998; 128:2779S-2782S

Kirk CP. Dogs have masters, cats have staff: Consumers' psychological ownership and their economic valuation of pets. Journal of Business Research. 2019;99:306-318.

Lue TW, Pantenburg DP, Crawford PM. Impact of the owner-pet and client-veterinarian bond on the care that pets receive. Journal of the American Veterinary Medical Association. 2008; 232(4): 531-540.

Mariti C, Gazzano A, Moore JL, Baragli P, Chelli L, Sighieri C. Perception of dogs' stress by their owners. Journal of Veterinary Behavior: Clinical Applications and Research. 2012; 7(4): 213-219.

McMichael AJ. Globalization, climate change, and human health. New England Journal of Medicine. 2013; 368(14):1335-1343.

Michel KE, Willoughby KN, Abood SK, Fascetti AJ, Fleeman LM, Freeman LM, Laflamme DP, Bauer C, Kemp BLE, Van Doren JR. Attitudes of pet owners toward pet foods and feeding management of cats and dogs. Journal of the American Veterinary Medical Association. 2008; 233(11):1699-1703.

Morris P, Knight S, Lesley S. Belief in animal mind: does familiarity with animals influence beliefs about animal emotions? Society \& Animals.2012; 20(3):211-224.

Odendaal JSJ. Die veearts en diereregte (the veterinarian and animal rights). J. S. Afr. vet. Assoc.1988; 59 (2):87-97.

Odendaal JSJ. Demographics of companion animals in South Africa. J. S. Afr. vet. Assoc.1994; 65(2): 67-72.

Paul ES, Serpell JA. Childhood pet keeping and humane attitudes in young adulthood. Animal Welfare. 1993; 2(4): 321-337.

Prato-Previde E, Fallani G, Valsecchi P. Gender differences in owners interacting with pet dogs: an observational study. Ethology. 2006; 112(1):64-73.

Preylo BD, Arikawa H. Comparison of vegetarians and nonvegetarians on pet attitude and empathy. Anthrozoös. 2008; 21(4): 387-395.

Reevy GM, Delgado MM. Are emotionally attached companion animal caregivers conscientious and neurotic? Factors that affect the human-companion animal relationship. Journal of Applied Animal Welfare Science. 2015;18(3):239-258. 
Rohlf VI, Bennett PC, Toukhsati S, Coleman G. Why do even committed dog owners fail to comply with some responsible ownership practices?. Anthrozoös. 2010; 23(2):143-155.

Roudebush P, Schoenherr WD, Delaney SJ. An evidence-based review of the use of therapeutic foods, owner education, exercise, and drugs for the management of obese and overweight pets. J. Am. Vet. Med. Assoc. 2008; 233:717725.

Sanderson S, Finco D, Pogrelis A, Stacy L, Unger C. Owner impressions of three premium diets fed to healthy adult dogs. J Am Vet Med Assoc. 2005;227:1931-6.

Scott P. What are companion animals? The Companion Animal Welfare Council. 2004; ( www.awselva.co.uk/cawc.pdf. Erişim: 19.07.2019).

Selby L, Rhoades A, John D. Attitudes of the public towards dogs and cats as companion animals. Journal of Small Animal Practice.1981; 22.3: 129-137.

Slater MR, Weiss E, Lord LK. Current use of and attitudes towards identification in cats and $\operatorname{dogs}$ in veterinary clinics in Oklahoma City, USA. Animal Welfare-The UFAW Journal. 2012; 21(1): 51.

Stamps J, Groothuis TGG. The development of animal personality: Relevance, concepts and perspectives. Biol. Rev. 2010; 85:301-325.

Talas, M. Sivil toplum kuruluşları ve Türkiye perspektifi. Türklük Bilimi Araştırmaları, 2011;29: 387-401.

Taylor N, Signal TD. Empathy and attitudes to animals. Anthrozoös. 2005;18(1):18-27.

Tekvar SO. HAYTAP'ın hayvan haklar1 mücadelesinde çatışmayönetimi: Hayvan hakları savunucularının kendi aralarında uzlaşması mümkün mü?. Uşak Üniversitesi Sosyal Bilimler Dergisi. 2017; 10(2):181-204.

Wrye J. Beyond pets: Exploring relational perspectives of petness. The Canadian Journal of Sociology / Cahiers canadiens de sociologie.2009; 34:1033-1063. 